\title{
Resistance as an enlightening process: a new framework for analysis of the socio-political impacts of place-based environmental struggles
}

\author{
Lea Sebastien $^{\mathrm{a}}$, Jerome Pelenc ${ }^{\mathrm{b}}$ and Julien Milanesi ${ }^{\mathrm{c}}$ \\ ${ }^{a}$ CNRS Geode Research Center, University of Toulouse II, Toulouse, France; ${ }^{b}$ Cedd-lgeat, Free University of Brussels, \\ Brussels, Belgium; 'CNRS Certop Research Center, University of Toulouse III, Toulouse, France
}

\begin{abstract}
One major feature of recent global environmental changes is the increasing number of local environmental conflicts throughout the world. However, there remains a lack of a comprehensive and dynamic framework to capture the socio-political transformations that placebased environmental resistance movements produce. Indeed, these conflicts are most often considered by dominant actors as a manifestation of the NIMBY (Not In My Backyard) phenomenon. In order to advance a framework capable of capturing the complexity of the socio-political effects of local environmental resistance movements, the goal of this paper is to further pursue the development of the concept of "enlightened resistance", which analyzes place-based struggles through four types of capital - social, knowledge, patrimonial and political - each with societal implications. This goal is mainly achieved through new conceptual and methodological developments in the framework which evolves towards an "enlightening resistance" framework, and through its application to three case studies from a comparative perspective. The authors develop a set of criteria in order to compare their case studies according to the four types of societal transformations that characterise the enlightening resistance framework. They argue here that this dynamic framework may be useful to the environmental justice movement to strengthen its capacity to assess the socio-political impacts of local environmental resistance movements.
\end{abstract}

\section{Highlights}

- The new framework proposed goes beyond the NIMBY concept and provides a comparative analysis for case-studies.

- Criteria are developed for identifying the socio-political transformations produced by place-based conflicts.

- The criteria and the concept of enlightened resistance may help environmental justice actors to build reflexivity.

- The framework's methodological developments enhance its reproducibility and thus it can be applied to/tested on other case studies.

\section{ARTICLE HISTORY}

Received 9 July 2018

Accepted 4 March 2019

\section{KEYWORDS}

Enlightened resistance; landuse conflict; environmental justice; comparative casestudy; socio-political transformation; NIMBY

\section{Introduction}

One major feature of recent global environmental changes is the increasing number of local environmental conflicts throughout the world (Escobar 2006; Martinez-Alier et al. 2016). Armiero and D'Alisa $(2012,53)$ ask the following question: "Are localized conflicts all affected by NIMBY syndrome or are 
they part of the many environmental justice conflicts emerging all around the globe?". Indeed, most of the time, planners, authorities, the media and to some extent researchers depict these local environmental resistance movements as a Not In My Backyard (NIMBY) phenomenon. In the NIMBY perspective, local opposition movements are seen as a form of deviant behaviour on the part of objectors guided by ignorance and self-interest, which represent an obstacle to public action and to the general public interest (Dear 1992; Armaiero and D'Alisa 2012; Batel and DevineWright 2015). Public and academic discourse continue to give credence to the term, but such analyses tend to project monolithic notions of opposition and fail to grasp the intricacies of local disputes (Sebastien 2017). As a result, the NIMBY significance remains very limited (Burningham 2000; Wolsink and Devilee 2009) and has therefore "left a lacuna that needs to be filled" (Devine-Wright 2005, 136).

In order to overcome this problem, Léa Sebastien $(2013,2017)$ has introduced the concept of "enlightened resistance", which offers a dynamic framework to analyze place-based struggles and to understand whether opposition movements operate solely from a self-centred position or from a public-interest position, as well as the possibility to navigate from the former to the latter. This concept highlights the importance of taking into account the temporal dimension when analyzing land-use struggles since these tend to last for years, allowing the representations, practices and knowledge of actors to change over time. This evolution is monitored through the production and use of four types of capital described hereafter (inspired from Bourdieu 1986): social, knowledge, patrimonial and political, which allow citizens to challenge the legitimacy of authorities by contesting their definition of public interest (Sebastien 2013, 2017). This reconfiguration by the participants involved in environmental resistance movements can further stimulate controversial democratic debate by revealing political relationships and asymmetries of power (Swyngedouw 2000; Mouffe 2005).

We argue that the enlightened resistance framework offers a relevant potential to further develop the understanding of socio-political impacts of place-based struggles within the field of environmental justice. Indeed, for environmental justice advocates, citizen opposition to new infrastructures represent a new era of ecodemocracy, where local opponents can question the notions of participation, decision making, progress and development and yet serve the general interest (Ford 2003; Holifield 2015). According to Anguelovski and Martinez Alier (2014), place-based struggles and local resistance movements represent common values and interests which often go beyond environmentalism itself. Along the same lines, Armiero and D'Alisa $(2012,57)$ explain that "these conflicts should be seen and analyzed as an experiment in new forms of participation, which are reshaping the borders among politics, science, and the self". Joan Martinez-Alier and his team (2016) conclude from their analysis of the world environmental justice atlas (ejatlas.org) that one of the most present outcomes is the strengthening of participation among the actors involved in the struggle. This result highlights the fact that the process of resistance is as important as the result. They explain that the analysis of "successes" in environmental justice (and their contextual meaning), and the alternatives that they give birth to, are now crucial topics that deserve further research attention.

The goal of the present paper is to further pursue the development of the framework of "enlightened resistance" in order to better characterise collective actions against new land-use facilities and to advance a more dynamic framework capable of capturing the complexity of the socio-political effects of local environmental resistance movements. This goal is mainly achieved through (1) new conceptual developments of the enlightened resistance framework complemented with the environmental justice literature; (2) the application of this dynamic framework to three case studies from a comparative perspective (a prison, a highway and a landfill) to demonstrate how the four types of capital evolved over time; (3) the proposition of specific criteria for each capital, important to take into account when analyzing land-use struggles. The article is structured as follows; Section 2 presents the enlightened resistance framework and the four capitals used in the analysis; Section 3 exposes our methods and cases; Section 4 details our results based on the case studies; Section 5 discusses the relevance of the framework and proposes a list of criteria corresponding to each type of capital involved in the resistance movement. 


\section{Theoretical framework}

\subsection{Defining the framework of "enlightened resistance" and explaining the use of "capital"}

"Enlightened resistance" was introduced for the first time by Léa Sebastien $(2013,2017)$ in reaction to the domination of the NIMBY approach which tends to depict local opponents as selfish, technophobic, unscientific and so on (Armiero and D'Alisa 2012; Batel and Devine-Wright 2015). In environmental planning, decision making regarding land use is increasingly controversial and these conflicts have proven much more complex than what can be explained simply as the NIMBY phenomenon (Gibson 2005). The ambition of the enlightened resistance framework is therefore to help better understand opposition movements as well as their societal and political impact, the latter point being poorly studied in the literature (Louis 2009). Vinthagen and Johansson $(2013,3)$ remind us that "resistance" is an oppositional act and hence it is rather a practice than a consciousness, but they also emphasise the need to think in terms of continuity between public confrontation and hidden subversion: "everyday resistance suggests that resistance is integrated into social life and is a part of normality; not as dramatic or strange as assumed - even if it is still unclear how common it is".

In studying place-based struggles, Sebastien (2017) shows that resistance movements can be

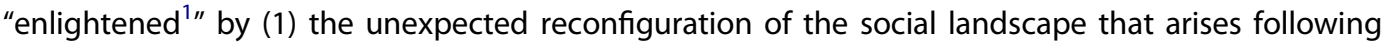
the organisation of resistance (social capital), (2) the rise of different types of legitimate knowledge concerning a territory (scientific capital), (3) the emergence and/or strengthening of place attachment (patrimonial capital), and (4) the politicisation of the movement (political capital).

The framework of enlightened resistance is based on the notion of capital, not as accumulation, but with reference to the theories of Bourdieu (1986), Putnam (2000), or Coleman (1988). Briefly, the capital constitutes certain attributes (economic, social, cultural, etc.) held by individuals (or groups). The concepts of social capital, knowledge capital (inspired from cultural capital) and political capital are used here regarding the approaches of these sociologists. The enlightened resistance framework adds the notion of patrimonial capital which corresponds to the place attachment felt by the people engaged in a place-based struggle, and which appears to be central in understanding the practices and representations of opponents (Sebastien 2016). We are very careful with the use of the notion of capital and are aware of its limits. We do not use it to study inequalities and social classes as in the Bourdieu approach, nor do we want to generalise the link between social capital, trust and democracy as Putnam attempted. Nevertheless, we argue here that this notion is helpful in analyzing the societal and political impacts of local environmental resistance movements.

All four capitals "enlighten" the resistance, transforming it with new social bonds, new knowledge, new attachments and a political dimension. The shift from being a self-interest to a public-interest movement is called enlightened resistance, which can enrich democracy through the constitution of these four types of capital. This shift leads involved citizens to challenge the legitimacy of authorities by contesting their definition of "common good" or "public interest" at different scales (Sebastien 2013).

\subsection{The four capitals: theoretical inputs}

One of the objectives of this paper is to better describe the links between the enlightened resistance framework and the environmental justice field. Therefore, in this section, each capital is presented according to the enlightened resistance framework which is based on Bourdieu's approaches (1981), and also from the perspective found in the environmental justice literature.

\subsubsection{Social capital}

Social capital is the resource, actual or virtual, that accrues to an individual or a group by virtue of possessing a durable network of more or less institutionalised relationships of mutual 
acquaintance and recognition (Bourdieu 1986). More simply, it refers to the network of social contacts and relationships that an individual can draw upon. Voluntary associations that enable a horizontal linking of people produce trust, which in turn leads to interpersonal bonding (Coleman 1988). This social capital is generated by the relationships created within a social structure and gives rise to social organisations making it possible to achieve previously unattainable objectives. A common local territory both induces and participates in the construction of social capital (Ghorra-Gobin 2001).

On place-based struggles, Sebastien (2017) shows that the resistance gathers people from different horizons and backgrounds (even with different political opinions) that would never have met without their opposition to the project. Yet, because they agree on the unjust nature of the project by mutually questioning its public utility, they can fight side by side. This result echoes the environmental justice literature, like Martinez-Alier et al. (2016) who explain that groups negatively impacted will often build coalitions with more powerful actors who may exert greater influence in order to develop a network for collective action. Usually, these alliances may include local scientists, recreational users, organised NGOs or trade unions. However, in some cases, as in the struggle reported by Armiero and D'Alisa (2012), activists may forge "highly unique and often unlikely alliances" (Swyngedouw 2000, 74) bringing together actors from different fields using different means of contestation (from legal procedure to direct illegal action), which may lead to tensions within the movement.

\subsubsection{Knowledge capital}

Aspects regarding an actor's knowledge are generally examined through what Bourdieu (1986) calls cultural capital, defined as the forms of knowledge, skills, education, and advantages that a person possesses, providing opportunities to achieve a higher social status. Concerning environmental conflicts, some researchers analyze what they call citizen knowledge (Brown 1992; Irwin 1995), the emerging intellectual capital which directly challenges the deficit model of public knowledge and understanding. Sebastien (2013) is particularly interested in knowledge acquisition over time within an association movement and therefore focuses on the different types of knowledge acquired (technical, legal, procedural, institutional, vernacular) during the process of resistance. The enlightened resistance framework therefore uses the term knowledge capital which includes the ability to gather data and facts, synthesise reports and to ask experts to promote other forms of knowledge (real-life experiences, common sense, local and practical knowledge).

Sébastien's results are in line with Burningham (2000), explaining that when laypersons acquire broad scientific knowledge, they are then capable of scientifically criticising the data, methods and technical aspects of a project, detecting diseases, generating hypotheses, questioning the environmental impact assessment provided by the promoters, pressing for state action and conceiving and overseeing scientific studies. In this sense, activists become "popular scientists" who can win the support of "professional" scientists. Engaged communities are recognised as producers of knowledge in their own right, rather than being merely objects of study. In environmental justice, popular or lay knowledge and experiences are just as valid as codified scientific or technical knowledge (Martinez-Alier et al. 2016). This knowledge production is required to contest the dominant valuation language, based on economic growth as a compensation for any losses (Anguelovski and Martinez Alier 2014). Finally, one could say that this process of knowledge development contributes to what Latouche (2015) called the "decolonization of the imaginary" pertaining to the dominant narrative of the project's promoters who see their project's public utility and the need for development and growth as indisputable. By forcing the opponents to seek alternatives, this process of knowledge production also fosters new imaginaries of what may be possible. Citizen initiatives can lead to counter expertise, situations called "scientific duels" (Busenberg 1999), where opponents bring along technical knowledge and expertise but also real-life experiences, common sense and knowledge, both local and practical. 


\subsubsection{Patrimonial capital}

Patrimonial capital is the only capital which does not come from Bourdieu's approaches; it is a direct input from the enlightened resistance framework. Patrimonial capital is derived from the notions of place attachment, place meaning and a notion which we call patrimonialization. Place attachment refers to emotional bonds between individuals and familiar locations (Altman and Low 1992) often featuring social and physical sub-dimensions (Hidalgo and Hernandez 2001). Place meaning refers to the symbolic aspects of territorial objects, enhanced through local practices (Brehm, Eisenhauer, and Stedman 2013). Patrimonialization refers to the dynamic among people, nature and tradition that helps to better perceive a territory (Micoud 2000). We thus call patrimonial capital the totality of bonding with the land, in both space (nature) and time (tradition) (Sebastien 2017).

Patrimonial capital has proven to be a central issue influencing representations and actions of opponents within a resistance movement (Sebastien 2016), therefore it is included in the enlightened resistance framework. For inhabitants, a territorial conflict can enhance a rediscovery of the territory under consideration, of its history and local heritage; for opponents who come from the exterior, the conflict can help to foster a new place attachment. As stated by Trom (1999), it is at times when we become indignant over a threat of change in our familiar environment, and when we wish to protest against this, that we show our concern for our attachment to territorial objects. In these situations, we are obliged to evoke the qualities of the countryside and of the territory, so as to share with others our way of visually relating to the surrounding world. Sebastien (2017) argues that place attachment and meanings may henceforth become part of the emergence of a collective identity. As Agnew (1987) says, meaningful places emerge in a social context and through social relations; they are geographically located and at the same time are related to their social, economic, cultural etc. surroundings, and they give individuals a sense of place, a "subjective territorial identity". Anguelovski and Martinez Alier (2014) also say that rural and urban actors in such conflicts appeal to local identities, cultural traditions, and to their right to place, attempting to protect and revitalise their rural or urban territories.

\subsubsection{Political capital}

Wishing to examine the social mechanisms producing and reproducing the gap between "active" and "passive" political agents, Bourdieu (1986) defines political capital as a form of symbolic capital founded on the innumerable operations of credit by which agents confer on a person the very powers that they recognise in him. Based on this approach, the enlightened resistance framework defines political capital as the capacity of different actors to place themselves on the political stage, based on their credibility (furnishing valid information), their salience (response to needs in the area of decision making) and legitimacy (as representatives of the area) (Sebastien 2017). For Simon and Klandermans (2001), the final stage in a politicisation process, after unfairness and distrust, is involvement in society at large. The protagonists henceforth act as representatives of social groups and no longer as individuals, meaning that a collective political identity emerges, identity being a place in the social world (ibid).

In the field, political capital can be seen via the opponents' capacity for bringing political (and legal) pressure to bear on federal, regional and municipal governments through a variety of legal and perhaps illegal actions (appeals to order, lawsuits, court cases, judicial activism, land occupations, protests, civil disobedience, art performances, public campaigns, official letters, the media, etc.). Armiero and D'Alisa (2012) explain that in general, people involved in place-based conflicts are "ordinary" people with no particular political experience. It is the deep need to defend their land or family that leads them to their first experience as political activists (they often do not recognise themselves as activists). For these political neophytes, involvement in local struggles gives them the opportunity to confront crucial questions such as: what is the political space in our community and who dominates it, what does personal mobilisation mean and "Who are we?" as a community (ibid). These issues, crucial for a healthy democracy, are not obvious and not very tangible until 
people are directly confronted with them. Finally, in the making of conflicts, new subjectivities, both individual and collective, are shaped and new reconfigured identities can emerge.

\section{Presentation of case studies and method}

\subsection{Selection of projects and opposition movements}

In order to test the robustness of the framework of enlightened resistance and to try to enrich it, three different case studies were chosen. We selected contested, territorial projects which varied in many aspects (scale, objective, cost, location, opposition movement, etc.), but which had a sufficiently long historical perspective allowing analysis of the evolution of the four capitals through time. The timeframe for our case studies therefore varies from 7 to 14 years of resistance. Concerning the variety in terms of the anchoring of each project, the first is a mega-prison to be constructed in a semi-urban area near Brussels, Belgium; the second is a highway impacting 52 rural communities between Pau and Bordeaux, France, and the third is a landfill planned in a village located south of Paris, France. Moreover, the cost, financing and scale of decision for each of the three projects reveal a diversity in terms of stakeholders involved, and in terms of project scope. Finally, each case presents a different degree of outcome: the landfill project was cancelled, the highway was constructed and the prison is still under discussion (Table 1).

\subsubsection{Opposition to the mega prison project in Haren (Brussels, Belgium)}

The prison project in the Haren neighbourhood (north of Brussels) was first presented to the inhabitants as an ordinary prison (400 prisoners) to be built on an already developed site as part of the federal jail master plan. At that time (2008-2011), the project was globally accepted by the people. In 2012, the project evolved towards a much larger facility planned to be built on the Keelbeek site, destroying a natural and agricultural environment as well as recreation spaces. In conjunction with other NGOs, the Haren committee began to organise various actions not only to protest the project, but also to inform the population as to its fallacies. Activists also discovered that many actors from the justice sector (magistrates, lawyers, human rights representatives, observatories of prisons, criminologists, etc.) were also opposed to the project, and in 2013, a colloquium was organised where academics, actors from the justice system, NGOs and local inhabitants met.

17th April 2014 was a turning point when 400 hundred environmental activists claiming food sovereignty came to Haren and started illegally planting potatoes on the project site. At harvest time, some activists decided to begin permanently occupying the site, and from autumn 2014 to September 2015, the land was occupied under the banner of "Zone to be defended" (ZAD), ${ }^{2}$ with activists coming from all over Europe. Various activities emerged on the site, such as agriculture, cultural events or craftwork, enabling the activists to inform people about the project and to delay construction of the prison. In September 2015, the area was evacuated by the federal police and fenced off, but this action was judged illegal and the site was re-occupied from September 2016 to the following

Table 1. Characteristics of selected case studies.

\begin{tabular}{|c|c|c|c|c|c|}
\hline Project & Location & $\begin{array}{c}\text { Area } \\
\text { impacted }\end{array}$ & $\begin{array}{l}\text { Scale of } \\
\text { decision }\end{array}$ & Time frame & Financing \\
\hline $\begin{array}{l}\text { Mega } \\
\text { prison }\end{array}$ & $\begin{array}{l}\text { Urban (Brussels, } \\
\text { Belgium) }\end{array}$ & 20 ha & $\begin{array}{l}\text { Federal, } \\
\text { Regional } \\
\text { and } \\
\text { municipal }\end{array}$ & $\begin{array}{l}\text { Project proposed in 2008; } \\
\text { ongoing negotiations } \\
\text { (9yrs); project seriously } \\
\text { delayed }\end{array}$ & $\begin{array}{l}\text { Public-Private partnership } \\
\text { between Belgian federal state } \\
\text { and a private international } \\
\text { consortium CAFASSO }\end{array}$ \\
\hline Highway & $\begin{array}{l}\text { Rural (New } \\
\text { Aquitaine, } \\
\text { France) }\end{array}$ & $\begin{array}{l}150 \mathrm{~km} \\
2000 \text { ha }\end{array}$ & National & $\begin{array}{l}\text { Project proposed in 1993; } \\
\text { opened in } 2010 \text { (7yrs) }\end{array}$ & $\begin{array}{l}\text { Concession contract with Eiffage } \\
\text { and SANEF groups for } 60 \text { years. } \\
100 \text { million } € \text { in public financing }\end{array}$ \\
\hline Landfill & $\begin{array}{l}\text { Rural } \\
\text { (St-Escobille, } \\
\text { France) }\end{array}$ & 150 ha & Regional & $\begin{array}{l}\text { Project proposed in 2002; } \\
\text { cancelled in } 2016 \text { (14yrs) }\end{array}$ & Private \\
\hline
\end{tabular}


spring. Concerning legal aspects, the environmental permit which was first delivered in June 2015 was rejected by the regional environmental council in December of the same year. However, the permit application was re-submitted in 2016 and accepted in March 2017, along with the building permit. In response, the opponents have since introduced several appeals against these permits. To protest against the construction that was about to begin, a new occupation was undertaken in April 2018, led by a dozen activists who took up permanent residence on the site.

\subsubsection{Opposition to highway a 65 between Pau and Langon (France)}

The initial ministerial decision concerning the itinerary of an expressway between the cities of Bordeaux and Pau was taken in 1996. The objective was then to connect the two major cities in Aquitaine via Langon and thus to cut through $150 \mathrm{kms}$ of the Landes forest and the agricultural uplands of Béarn. The first associations were thus created in several villages to be affected by this route. The project was truly launched in 2003 , in the form of a call for bids. In autumn 2005 , the state finally opted for the solution of a freeway along the route's entire length. New local associations then emerged, structured within a single regional organisation (Alternative régionale Langon Pau) and were joined by the SEPANSO (large regional association for defense of the environment, affiliated with the French federation of environmental associations France Nature Environnement), various political parties and employee unions.

The mobilisation organised around the public inquiry carried out in spring 2006, in particular by developing arguments concerning the project's lack of economic viability and its ecological impact in terms of biodiversity and climate. In June of that year, an associative and festive event was organised in the Landes department where representatives of national environmental organisations and associations opposing highway projects were present and signed a national call for highway moratorium. In December 2006, the project's public utility was officially recognised and the contract awarded. The conflict hardened and the controversy began to be relayed in the national media, especially during the environmental summit conference (Grenelle de l'environment) organised by the government in autumn 2007. Clearing work began in early 2008, but in March of that year the French National Council for Nature Conservation (CNPN), advisory body to the Ministry of Ecology, issued an unfavourable opinion on the project which was then frozen. Opponents launched the movement "Volunteer Planters", replanting trees on the areas already cleared. After amendments, especially concerning ecological compensation measures, the CNPN finally approved the project. Work began in September 2008 and the highway was inaugurated on 16 December $2010 .^{3}$

\subsubsection{Opposition to the Iandfill in Saint-Escobille (France)}

The landfill project in question was in Saint-Escobille, a small rural locality (450 inhabitants) $50 \mathrm{~km}$ from Paris, located in the extreme southwest of the Essonne department, in the Beauce region which is one of the most important agricultural areas in France. In 2002 an inhabitant of a neighbouring village proposed 46 acres (19 hectares) of land located within the township of Saint-Escobille to a large company then seeking a site for a landfill. On this agricultural land, the promoter hoped to construct a landfill centre with a burial capacity of 150,000 tons of ordinary industrial refuse per year over a period of 10 years. The same year, a non-profit association was created called the ADSE (Association pour la defense de Saint-Escobille) which counted about a hundred members and whose president was the village mayor.

In 2005, public protests against the landfill began, and the ADSE took its first political stands when the association published a proposal entitled "Moratorium on Landfills and Final Waste". In 2007, the public inquiry issued a negative opinion on the proposal to modify the area's land-use plan (the request to approve a landfill centre in agricultural zones). Nevertheless, the prefect - the local appointed authority of the central government - demanded in 2009 that the project be recognised as being of public utility, in disagreement with the opinion of the Regional Council of lle-de-France which normally has jurisdiction in matters of waste management planning. While organising many demonstrations, the ADSE filed an appeal against this order, receiving the formal support of 27 
elected officials at all different political levels, 132 municipalities spread over several departments, 11 agricultural groups and 43 associations. In 2011, the president of the association appeared before the Commission of Petitions of the European Parliament to lead inquiries about waste management in France and in Europe. In 2013, the Versailles court of appeals cancelled the label of public utility regarding the Saint-Escobille landfill project. In 2015, despite the request from the promoter to reconsider the decision of the French state council (Conseil d'Etat), the Versailles court of appeals reconfirmed its decision and in 2016 , the initial landfill project was considered officially inappropriate for this territory.

\subsection{Methodological approach}

To estimate the evolution of the different capitals within a territory and over time, the literature offers no tool that matches the comprehensiveness of the enlightened resistance framework, and there is no consensus as to the methodology to adopt regarding how to individually measure each type of capital. Though we can borrow some methods from the analysis of separate capitals such as the social (Grootaert 1999) or patrimonial capitals (literature from place attachment - see Sixsmith 1986 or Raymond, Brown, and Weber 2010), no specific work analyzes all four capitals within a placebased struggle, nor the capitals taken all together, nor when approached through a dynamic framework. The only position found in the literature about strengthening the role of empirical evidence in debates on social capital, civil society and citizenship (Van Deth 2003) is that mixed methods are recommended (Silva, Wright, and Ward 2009), stating that the integration of quantitative and qualitative methods may yield better results (Dudwick et al. 2006). Our study is therefore exploratory and proposes some methodological inputs in order to analyze place-based struggles over time and based on the evolution of the four types of capital (social; knowledge, patrimonial and political). This "enlightening" process can only be examined through a lengthy temporal frame (Sebastien 2017) by studying different phases within an opposition movement. To enhance and formalise the dynamic aspect of the enlightened resistance framework, we propose to study environmental resistance movements as follows: (1) the pre-existing situation, (2) the moments of change and (3) the built up capitals (Table 2). The integration of this temporal triptych into the framework allows us to prefer the term "enlightening" resistance, which highlights the importance of the temporal dimension of resistance and specifies the enlightening process that we want to analyze.

In order to apply the temporal triptych of the enlightening resistance framework to our three case studies in a comparative perspective and to analyze the evolution of the four capitals within resistance movements, we first collected data from a wide variety of sources:

- scientific literature on the impacts of similar projects (prisons, highways, landfills)

- press releases from different levels (local, regional, national)

Table 2. The enlightening resistance framework to analyze the evolution of resistance movements within a place-based struggle.

\begin{tabular}{|c|c|c|c|}
\hline & Pre-existing capital & Moments of change & Built-up capital \\
\hline Social capital & $\begin{array}{l}\text { Types of networks existing on site prior to } \\
\text { project announcement }\end{array}$ & $\begin{array}{l}\text { Types of actions undertaken } \\
\text { in relation with other actors }\end{array}$ & $\begin{array}{l}\text { Types of networks emerging } \\
\text { within the movement, either } \\
\text { horizontally or vertically }\end{array}$ \\
\hline $\begin{array}{l}\text { Knowledge } \\
\text { capital }\end{array}$ & $\begin{array}{l}\text { Types of education levels, skills and } \\
\text { knowledge (institutional, legal, scientific, } \\
\text { vernacular, etc.) among protesters existing } \\
\text { prior to project announcement }\end{array}$ & $\begin{array}{l}\text { Types of actions undertaken } \\
\text { in relation with skills and } \\
\text { knowledge development }\end{array}$ & $\begin{array}{l}\text { Types of skills and knowledge } \\
\text { developed through the } \\
\text { resistance process }\end{array}$ \\
\hline $\begin{array}{l}\text { Patrimonial } \\
\text { capital }\end{array}$ & $\begin{array}{l}\text { Types of attachments to place existing prior } \\
\text { to project announcement (individual and } \\
\text { collective; in time or space) }\end{array}$ & $\begin{array}{l}\text { Types of actions undertaken } \\
\text { in relation to heritage }\end{array}$ & $\begin{array}{l}\text { Types of new patrimonial capital } \\
\text { developed during the conflict } \\
\text { concerning the place in } \\
\text { question }\end{array}$ \\
\hline $\begin{array}{l}\text { Political } \\
\text { capital }\end{array}$ & $\begin{array}{l}\text { Types of associations with a political } \\
\text { dimension in the territory prior to project } \\
\text { announcement }\end{array}$ & $\begin{array}{l}\text { Types of actions undertaken } \\
\text { in relation with political } \\
\text { positioning }\end{array}$ & $\begin{array}{l}\text { Types of politicisation of the } \\
\text { movement }\end{array}$ \\
\hline
\end{tabular}


- political strategies regarding waste management, prisons, transport

- collection of planning inquiry documents

- analyses of websites (project promoters, opposition movements, etc.).

Secondly, in order to compile such delicate information as that dealing with the evolution of social networks, of knowledge acquisition, of place attachment and of political involvement, it appeared necessary to conduct interviews with the actors involved in and affected by the project. All in all, we undertook 30 semi-structured interviews (10 per case) with the objective of meeting a variety of opponents within each movement (initiator, leader, distant, new member, inhabitant, opponent from outside the area, occupying activist, urban, rural, etc.). The objective of this approach was not to draw a statistically representative sample, but to obtain a wide range of variety in the responses. Opponents' discourses were analyzed collectively per case, as the idea was not to pursue a sociological analysis of each activist, but to try to decrypt the evolution of actions undertaken in common.

Finally, our regular presence in the field from the start of the mobilisation for each case allowed us to analyze, through the methodology of participant observation, how the content of protesters' arguments changed over time. By attending meetings, public events and demonstrations, we were able to follow the evolution of the four capitals in parallel with the progression of the conflict situation. By implementing this structured threefold methodological approach similarly for each case, we obtained a comparative analysis of the three opposition movements. Our results are presented per capital and through our temporal triptych.

\section{Results: the evolution of the four capitals in our three case studies}

\subsection{Social capital}

Here we wish to depict different kinds of networks that may arise from opposition movements and analyze the evolution of social capital through time. Pre-existing social capital refers to the types of networks existing onsite prior to the project announcement. In the prison and landfill cases, this preexisting capital was limited to cultural or sports associations. Concerning the highway, the social capital prior to the conflict differed depending on the village concerned, but was inexistent on a regional scale. Before identifying the moments of change, it is interesting to qualify the actor initiators of the movement (Who are they? How many people and from what horizons? Are they internal or external to the area in question?). In our three cases, the mobilisation was initiated by local inhabitants who created an association in order to fight the project, together with political parties in the highway case and local political representatives in the landfill project.

These initiator groups began to implement actions in relation with the social capital, actions which represent the moments of change. The first action taken by all three associations was to make contact with a series of other actors aiming at supporting them in their struggle: regional NGOs for the mega prison; ecological associations and a series of experts (lawyers, doctors, hydrologists, etc.) for the landfill; for the highway, the different village associations merged into a single main collective and began collaborating with regional ecological associations. The variety of actions undertaken in our case studies fell into five categories: political (petitions, letters to politicians, etc.), legal (lawsuits, procedures, etc.), artistic (paintings, movies, poems, etc.), media (press articles and releases, etc.) and illegal direct action (civil disobedience, unauthorised demonstrations, etc.). ${ }^{4}$ We note an important evolution in the number of people participating in the movements in all cases. The prison movement, after 9 years of existence, has seen the number of participants increase from a small core group of 1020 persons working on a regular basis to 400 persons for specific events. For the highway movement, after 7 years of existence, 30 persons represented the core group, with 200 members in the association. Regarding the landfill movement, it reached 1000 members after 14 years of existence, with 5 persons working regularly. Another similarity among cases is the evolution of the movements' heterogeneity which can enable a movement to evolve rapidly, based on the complementarity of its 
members. In our three cases, the movements' heterogeneity was obvious, with some differences nevertheless. The prison case brought together mainly activists, yet from very different spheres (anti-prison, ecology, law, agriculture) and local inhabitants; the highway movement attracted labour union members and political activists, but did not succeed in mobilising rural actors (hunters, foresters, farmers); and for the landfill, the movement associated elected officials of all political parties, farmers, professionals and retirees, ecologists and city dwellers, profiling a very diverse population, though with very few actors from outside the territory.

The built-up social capital represents the types of networks that emerge with the movement, either horizontally (local actors, activists, etc.) or vertically (experts, scientists, politics, etc.). In the prison cases, several improbable alliances were built, gathering a wide variety of actors from both the justice/human rights sectors (the judiciary, international observatory of prisons, anti-prison activists, etc.) and from among environmentalists (environmental NGOs, food sovereignty activists, urban agriculture NGOs, etc.) all together with the local inhabitants and activists who occupied the threatened field. Moreover, four organisations were created: two relatively informal ones, "The Free Keelbeek" collective and the "Haren Observatory", and two more formal ones, the "Platform against Prison Disaster" and the "Gardeners' Forum". In the highway case, despite the geographical remoteness of villagers impacted by the project, we can also note the development of a dense network of local and regional, but also national NGOs working on other similar cases in France. In the landfill case, the built-up capital is also impressive and shows the structuration of a technical network of experts from a local network of rural and urban actors, and also from an associative network of rural and ecology activists working on waste management or environmental protection, both in France and abroad.

\subsection{Knowledge capital}

Here we depict the acquisition and mobilisation of different types of knowledge found within resistance movements. In our cases, the pre-existing knowledge capital is, for example, poor on imprisonment issues among the inhabitants mobilised against the mega-prison project given that the general population is not usually confronted with this issue. Some knowledge on road issues existed at the beginning of the movement against the highway because some members worked in this sector, others had a good knowledge of biodiversity issues, as in law or economics. In the landfill movement, the knowledge capital prior to the conflict showed some political and legal knowledge. If we look at the opponents' degrees, professional qualifications and work experience, in the three movements under study, higher education degrees are diverse, varying considerably in the prison and highway movements, with an overall low level in the landfill movement.

To apprehend the moments of change, let us examine the actions implemented in relation to knowledge acquisition and diffusion by the opponents, based on this pre-existing capital. The indepth analysis of official documents concerning the project is a feature common to all three movements. The highway and prison opponents also contacted local NGOs specialised in ecological issues to build up their counter expertise. The actions undertaken in relation to knowledge acquisition by the landfill movement were the investigation of the best available technologies, the compilation of studies on landfill impacts, analysis of impact studies, contacts with experts, presence at conferences and the questioning of scientists.

To be efficiently used and communicated, this knowledge capital needs to be shared and to circulate among members of the movements. In the three cases, we witnessed an interesting complementarity among different groups of opponents, from those who bring empirical facts or real life experiences from the field, to those who possess legal, strategic and communication skills, and to others who bring more emotion and energy for direct action. The prison movement was quite inventive in this area, developing a cross-learning and systemic approach that helped opponents to link problems together through a variety of methods (colloquium, festival, film making, drawings, nature walks, etc.). The movement against the highway used internal meetings and different types 
of events (film projections, conferences, group hikes, data exhibitions, etc.) to spread information acquired by its members throughout the movement (knowledge of road issues, biodiversity, economics, accounting or climate change). A great complementarity also developed among activists in the movement against the landfill, with specialists for each type of knowledge: scientific, legal, institutional, common sense, etc.

Another similarity among our cases is the ability of opponents to contest official knowledge. The prison opponents deconstructed the environmental impact assessment, the federal prison policy and legal and technical procedures. They also radically contested the compensation language held by the promoters of the project ecologically (vegetal transplantation, creation of a park), economically (rejection of economic compensation) and politically (contestation of agreements between different parties). The highway opponents also contested the arguments on ecological compensation, but mainly focused their efforts on contesting the economic and financial equilibrium of the project. Activists against the landfill contested scientists' knowledge in relation to uncertainties about waste disposal. Thus in all three movements, the built-up knowledge capital reflected solid scientific, legal, technical, political and procedural knowledge.

\subsection{Patrimonial capital}

We are interested, here, in identifying the various place attachments and meanings in conflictual areas and exploring their evolution over time. The pre-existing patrimonial capital refers to the types of attachments existing prior to project announcement. This information is not easy to collect, firstly because place attachment is a domain related to emotions and feelings, that actors do not feel comfortable discussing, and secondly, because depending on the time of study, the researcher will often have to grasp the patrimonial capital retroactively, in order to have an idea of "how it used to be". Nevertheless, as a specific threat to a loved area obliges people to express their feelings, the greater a project's impacts, the more people identify precisely what relates to their heritage in the area (Sebastien 2016). In the prison and landfill cases, the pre-existing patrimonial capital was quite low except for some native farmers attached to the earth and the landscape, but neither region (suburbs of Brussels and grain-producing plains south of Paris) were considered of any interest to outsiders. The specificity of the highway is that it covers $150 \mathrm{~km}$ in different landscapes, therefore the pre-existing patrimonial capital was higher than for the other case studies, but was widely dispersed and with no collective identity.

The moments of change are examined through the analysis of the actions implemented by the movement in relation to expressed attachments. In all three cases, these were numerous and widely varied, based on artistic demonstrations, games or fun activities, such as concerts, auctions, thematic evenings, heritage days, debates, etc. Songs and poems were created in the Beauce region whereas theatre plays or drawings were proposed in the highway case, underlying the artistic side of the mobilisation. All these actions aiming to protect the common heritage have social and spatial implications. First, how are place attachments and meanings being transmitted (or not) to other actors? Here we focus on the pathway between individual and collective attachment. The transmission of patrimonial capital was very important in all cases, with the creation of new social networks around liked entities, and unusual solidarities and proximities among actors within the territory, and also between local actors and outsiders, people from elsewhere but who were willing to join the fight to protect what was considered to be a common heritage. Nevertheless, this cohabitation may sometimes generate tensions such as in the prison case, where some "occupiers" could have claimed that they were more legitimate than the inhabitants regarding the management of the site, and vice versa. Second, does place attachment enhance specific practices in the territory? In the prison case, due to the occupation, opponents discovered and co-produced many ecosystem services which were no longer provided at the site, notably provisioning services (vegetable garden, orchard, water, flower and fruit gathering, firewood, etc.). The "living experience" of the occupation played a key role in the connection with nature. The struggle triggered, at least 
with the most involved actors, a reflection on the future of Haren in order to recover/re-create a part of the rural identity. In Beauce, among diverse spatial implications such as knowledge about the area and actions at different levels (local, regional, national, European), the movement activists discovered a Gallo-Roman site and undertook the protection of abandoned wetlands and a local bird, the Montagu's harrier. For the highway, many animal and vegetal species were discovered along the route, especially at the Nine Fountains site, enhancing the opponents' ecological knowledge.

To sum up, let us look at the built-up patrimonial capital, which shows whether new patrimonial capital has been acquired during the site conflict. Indeed, it has been clearly enhanced in our three case studies, especially in Beauce and Haren, where it was particularly low before the conflict. In Beauce, concerning historical heritage, there was a collective appropriation of the waste history of the area; as for the territory, despite its bad image, a strong collective place attachment was developed. In Haren, place attachment was heavily reinforced for local inhabitants, and outsiders "fell in love" with the site even though it is surrounded by infrastructural facilities.

Our analysis reveals the existence of an emblem of the fight in all three cases, in other words a territorial object that crystallizes attention on the conflict. For the landfill, the emblem of the mobilisation was the good earth of Beauce, and for the mega prison case, it was the cultivation of chicory, an activity that originated in this area and which helped to create a shared place attachment among both inhabitants and outsiders. In the highway conflict, a wetland called the "Nine Fountains" became the federating element of the fight. Composed of three ponds, an eighteenth century farmhouse and the village wash-house, the site was completely unknown before the project was announced.

\subsection{Political capital}

We depict here the different paths towards a politicisation process in our case studies. The pre-existing political capital refers to the presence (or not) of associations with a political dimension in the territory concerned by the project facility. It is worth noting that in the three cases, a significant part of the actors had no previous experience of activism or political experience. In Beauce and Haren, only local cultural and hobby associations previously existed in these areas. Concerning the highway, it depended on the village concerned but no group made any political claim over the entire territory.

Moments of change are revealed through the diversity of actions undertaken. As political positioning is a complex phenomenon, we argue that it can only be based on a combination of widely differing actions. This heterogeneity of action relates to the social heterogeneity examined in the social capital section, where complementarity among members enriches the movement and causes it to evolve towards a political positioning. In our three cases, the actions undertaken by the movements were highly diverse, touching the legal sphere (lawsuits, court cases, appeals to order, etc.), the decision-making sphere (official letters, public campaigns, petitions, etc.) and the public sphere (the media, art performances, marches, etc.), but only the prison case experienced an occupation of place.

In all three cases these actions related to the political capital lead to three types of evolution regarding the movement and which represent the built-up political capital: the proposition of alternatives (to the project, and to decision-making processes); the broadening of issues (in terms of themes and scales); a long-term vision (for the association and the territory).

Concerning alternative propositions to the project, in our three cases, activists were able to propose detailed alternatives to the promoter. In the prison case, opponents proposed an "open farm" project offering rehabilitation activities, a counter-project which sprang from the land occupation that played a strong role in decolonising the imaginary showing by doing, demonstrating, in fact, that another future is possible. In the landfill case, there were many project propositions such as small waste treatment plants, eco-conception, industrial ecology, bio-methanization, the circular economy and waste sorting. As for the highway, from the very beginning of the project the 
opponents proposed and defended the improvement of the existing road. As for alternatives regarding decision making, interviews with opponents clearly show that to fight an infrastructure is also to fight political, administrative and judicial procedures. Activists felt a crude lack of democracy and realised that the decision-making process is opaque and often biased, and therefore wished to denounce these procedures by proposing alternative ways of deliberating and taking decisions, ways that they often implemented within their movements. Our three cases show a deep mistrust of and disappointment in institutional actors and participative procedures, and many discussions with the movements were about democratic principles. In the prison and landfill cases, activists tried to convince decision makers in both France and at the European Union level to organise processes for true citizen participation, to enhance the role of associations, or to limit the power of government representatives.

Concerning the broadening of issues, first, a reframing of the scale of arguments is observed within our three movements, starting from local interest and moving towards public interest at the national level and beyond. In the prison case, we observed in the discourse of the inhabitants a scaling up of the claims starting with the preservation of local landscapes and local mobility problems, to the contesting of the federal imprisonment policy and initiating a strong debate about it. The "platform against prison disaster" played a role at the national level, advocating a moratorium concerning prison policy, in addition to other policies, while the "gardeners forum" played a role at the regional level, claiming the right of the citizens to actually participate in the making of the city. The local contestation to the highway also had a national impact, both in the media and also at the policy level where opponents enhanced regional and national networks, aiming to completely change transport policies with a proposition of a national moratorium on highways. Similarly, in Beauce, opponents now work on regional, national and European actions concerning waste issues generally. Second is the broadening of themes that can be observed within opponents' arguments, which is obvious in our cases. In Brussels, an important political outcome was to foster, through the creation of the "gardeners forum", the debate on the rapid urbanisation process in the Brussels region. We also observed a thematic broadening of the claims from anti-prison to food sovereignty to the "right to the city" and to the complementarity of legal and "illegal" means of action. In the highway case, various general environmental associations were created following the struggle. In Beauce, in 2011, the association ADSE or Association de Défense de St-Escobille decided to change its name for Association de Défense pour la Santé et l'Environnement in order to highlight this broadening theme.

Finally, we note in all cases the ability of opponents to propose a long-term vision for the territory as well as for the movement's existence. What is the situation of the opponents in their territory in the long run? What becomes of the association after the end of the struggle? This is particularly true in Beauce, where the association set for itself the objective of reaching a zero-waste territory and takes positions on various environmental themes even though the landfill project has now been cancelled. This long-term vision is also present in the two other cases, though less clearly. For the highway, the fact that the project has been implemented has cut the movement into two parts: those who were discouraged and abandoned the fight, and those who are now involved in other environmental causes. For the prison case, as the struggle is ongoing, it is difficult to evaluate the opponents' long-term vision, but their discourse today reveals the objective of continuing the fight in the future and some of the inhabitants, inspired by the occupation of the field, have taken up different agricultural activities elsewhere in their neighbourhood. The built-up political capital is therefore consistent in our three resistance cases, based on the proposition of alternatives, the broadening of the issues and the long-term vision. The following table sums up the "enlightening" process in our cases, presented per capital and within our temporal triptych (Table 3).

\section{Discussion}

Our discussion is dedicated to the identification of what arises from the comparison of the evolution of the four capitals across our three case studies. These similarities are put forward here as criteria to 
examine when studying resistance movements to land-use facilities. Concerning social capital, our analysis highlights the criteria of density and heterogeneity within opposition movements as interesting elements to focus on when examining network changes within a movement. Density is examined through the evolution of the number of members of an association over time, from the movement's beginnings. Heterogeneity looks at the type of actors involved in the movement (neighbourhood, occupational, economic status, religious, gender, age, etc.).

Concerning knowledge capital, the two issues that are common to all three of our cases are contested knowledge and complementary knowledge. Contested knowledge indicates the different types of knowledge built up by the movements, in opposition to official knowledge. Complementary knowledge refers to the organisation among members for preparing knowledge acquisition. These two indicators emerge in all cases and should be taken into consideration when studying knowledge changes in a resistance movement.

As for patrimonial capital, we noted in our cases the emergence of an emblem of the fight, a territorial object characterising the endangered place and highlighted by the activists. This emblem represents an entity which brings together all the opponents and reinforces the patrimonial capital. The second criteria brought forth by our results is the social implication of patrimonial capital, in other words the type of transmission of place attachment among actors. This transmission creates a link between patrimonial capital and social capital. The third criteria we wish to focus on concerns the spatial implications of patrimonial capital, explored through knowledge acquisition concerning the territory and the involvement in protective practices, enhancing a link between patrimonial capital and knowledge capital.

Finally, when analyzing the politicisation of resistance movements, we wish to advance three issues which emerged in all three of the studied cases. The first is the proposition of alternatives by opponents, both in the project and in decision making. The ability of the movement to propose credible alternatives regarding the project is related to technical knowledge capital, allowing citizens to become experts on the subject matter. The ability of the movement to propose credible alternatives regarding decision making is related to institutional knowledge capital, allowing citizens to become legitimate in proposing alternative ways of deliberating and making decisions, ways that are often implemented within resistance movements. Next comes the broadening of opponents' arguments in terms of scales and themes. We show that the possible deterioration of liked entities induces actors to rally to their defense, to collect information, first about the liked entities themselves and then more broadly, on associated themes, and to propose alternatives,

Table 3. Overview of results.

\begin{tabular}{|c|c|c|c|}
\hline & Pre-existing capital & Moments of change & Built-up capital \\
\hline Social capital & $\begin{array}{l}\text { Few networks existing prior to } \\
\text { project announcement in all our } \\
\text { three cases }\end{array}$ & $\begin{array}{l}\text { Wide diversity of strategies to build } \\
\text { dense networks of cooperation } \\
\text { implying a great heterogeneity } \\
\text { of actors }\end{array}$ & $\begin{array}{l}\text { Creation of diverse collective } \\
\text { bodies: local, regional, national } \\
\text { NGOs, civil society organisation, } \\
\text { citizens collectives, etc. }\end{array}$ \\
\hline $\begin{array}{l}\text { Knowledge } \\
\text { capital }\end{array}$ & $\begin{array}{l}\text { High variety of education degrees } \\
\text { and work experiences among } \\
\text { protesters but poor knowledge on } \\
\text { project issues (prison/waste/ } \\
\text { transport) }\end{array}$ & $\begin{array}{l}\text { Various and complementary } \\
\text { actions for knowledge } \\
\text { acquisition and contesting of } \\
\text { official knowledge }\end{array}$ & $\begin{array}{l}\text { Solid scientific, legal, technical, } \\
\text { political and procedural } \\
\text { knowledge developed through } \\
\text { the resistance process }\end{array}$ \\
\hline $\begin{array}{l}\text { Patrimonial } \\
\text { capital }\end{array}$ & $\begin{array}{l}\text { Some individual attachments but no } \\
\text { collective attachments among } \\
\text { inhabitants; no attachment from } \\
\text { outsiders }\end{array}$ & $\begin{array}{l}\text { Numerous actions based on artistic } \\
\text { demonstrations, cultural events } \\
\text { and fun activities }\end{array}$ & $\begin{array}{l}\text { Collective appropriation of the } \\
\text { territory, transmission to other } \\
\text { actors and protection of emblems }\end{array}$ \\
\hline $\begin{array}{l}\text { Political } \\
\text { capital }\end{array}$ & $\begin{array}{l}\text { No association with a political } \\
\text { dimension in the concerned } \\
\text { territories }\end{array}$ & $\begin{array}{l}\text { Diversity of actions undertaken by } \\
\text { the movements touching the } \\
\text { legal, the decision-making and } \\
\text { the public spheres }\end{array}$ & $\begin{array}{l}\text { Propositions of alternatives (to the } \\
\text { project, to decision-making } \\
\text { processes); broadening of issues } \\
\text { (in terms of themes and scales); } \\
\text { long-term vision (for the } \\
\text { association and the territory). }\end{array}$ \\
\hline
\end{tabular}


Table 4. Proposition of criteria to examine when analyzing resistance movements within place-based struggles.

\begin{tabular}{|c|c|c|}
\hline Capitals & Criteria & Definition \\
\hline \multirow[t]{2}{*}{ Social capital } & Density of associations & Evolution of the number of members \\
\hline & Internal heterogeneity & $\begin{array}{l}\text { Types of actors involved in the movement (neighbourhood, occupation, economic } \\
\text { status, religion, gender, age) }\end{array}$ \\
\hline \multirow{2}{*}{$\begin{array}{l}\text { Knowledge } \\
\text { capital }\end{array}$} & Contested knowledge & Type of information denounced by protesters \\
\hline & $\begin{array}{l}\text { Complementary } \\
\text { knowledge }\end{array}$ & The organisation among members to prepare knowledge acquisition \\
\hline \multirow{3}{*}{$\begin{array}{l}\text { Patrimonial } \\
\text { capital }\end{array}$} & Emblem of the fight & Entity characterising the endangered place and highlighted by activists \\
\hline & Social implication & Transmission of patrimonial capital to other actors \\
\hline & Spatial implication & $\begin{array}{l}\text { Knowledge acquisition about the territory and protective actions towards liked } \\
\text { entities }\end{array}$ \\
\hline \multirow[t]{5}{*}{ Political capital } & $\begin{array}{l}\text { Alternatives for the } \\
\text { project }\end{array}$ & Proposition to promoters of credible alternatives to the project \\
\hline & $\begin{array}{l}\text { Alternatives for } \\
\text { democracy }\end{array}$ & $\begin{array}{l}\text { Debates on the notions of participation, decision making, progress and development } \\
\text { and use of emergent democratic principles within the movement }\end{array}$ \\
\hline & Scaling-up of claims & $\begin{array}{l}\text { Reframing of the scale of arguments, from local interest to public interest on the } \\
\text { national level }\end{array}$ \\
\hline & Broadening of themes & Claims become more general and included within a collective cause \\
\hline & Long-term vision & $\begin{array}{l}\text { Position of opponents within their territory in the long run and concerning } \\
\text { association projects after the end of the struggle }\end{array}$ \\
\hline
\end{tabular}

first locally, then regionally and later nationally. Our last criteria concerning political capital, and that the different case studies share, is the movement's temporal dimension and the movement's ability to propose a long-term vision for the resistance movement as well as for the territory.

Our comparative analysis of 3 place-based resistance movements has enabled us to identify key elements to be studied in order to better characterise the processes of "enlightening resistance". Our results echo the environmental justice literature, reflecting the idea of an opposition movement which can be transformed into a proposition movement. We argue that these criteria should be investigated in other cases and may be of use to the environmental justice movement to better grasp the socio-political effects of environmental resistance. An overview is provided in the table below (Table 4):

\section{Conclusion}

Based on the concept of enlightened resistance (Sebastien 2017), this paper is an attempt to qualify the evolution of four types of socio-political impacts (i.e. capitals) that are produced through an opposition movement taking place within a given territory. To achieve this, we undertook a comparative analysis of three different cases of land-use struggles (a landfill, a highway, a prison), in order to help us better understand what brings opponents together in their fight against disparate infrastructures in other words, to look for the unity in diversity.

This paper offers four main contributions: (1) a theoretical input through the strengthening of the enlightened resistance framework using the environmental justice literature; (2) a methodological input through the improvement of the dynamic aspect of the framework, called enlightening resistance, designed to foster a better understanding of the evolution of land-use struggles over time; (3) an empirical input through the application of this dynamic framework to three case studies from a comparative perspective (a prison, a highway and a landfill) to demonstrate how the four types of capital evolved over time; and (4) a discussion input through the proposition of a list of criteria that should be taken into account when studying resistance movements to land-use facilities. Therefore, the four-capitals model can help to better analyze how local environmental resistance movements contribute to the global environmental justice endeavour. Our contributions lead to a series of questions and require improvements.

A first question that must be further examined is: how can we better formalise analysis of the interaction between capitals? According to Bourdieu (1986), the conquest of social capital requires the construction and maintenance of a "sustainable network of relationships" which can be transformed 
into political capital. Likewise, for Putnam (2000), social capital amounts to a direct test of the democratic strength. A hypothesis of the enlightened resistance framework is that social capital is necessary though insufficient by itself to become political capital. Regarding land-use conflicts, it is knowledge and patrimonial capitals which enable social capital to evolve into political capital (Sebastien 2017). In our cases, we validate this hypothesis, considering types of involvement in society (political capital), as dependent on the development of the three previous capitals. Nevertheless, this development is not linear and each conflict presents a specific configuration of the four capitals which is context-dependent and which presents a character changeable with time. We are particularly interested in being able to characterise the evolution of political capital in case studies, based on analysis of the three other capitals and we argue that this hypothesis should therefore be examined further and tested on other resistance cases, in order to better analyze the interactions between capitals.

Concerning the framework, its dynamic aspect seeks to capture the state of a movement at a given moment of its evolution, but in no way do we expect to grasp the movement's very essence which might give an indication as to its political legitimacy. There is no ideal temporality in the use of this framework; it can be mobilised at the beginning as well as at the end or in the middle of a conflict. It would be interesting, in future studies, to test the framework's ability to represent the evolution of movements by using it at different points in time and over differing periods in order to improve its dynamic aspect.

As for the criteria, it goes without saying that this first list should not focus attention solely on these movements. Though based on a panel of cases and contexts that we intended to be widely diversified, this analysis could be enriched by being confronted with other case studies, other contexts, with singular characteristics that may have eluded us here, in order to better test the transferability of the framework.

Finally, we conceive of this framework as a tool for use by the scientific community, in order to apprehend these movements as social phenomena, but also for use by the movements themselves. The framework of analysis for enlightening resistance, can indeed be used by activists as a reflective tool, which we also assume to be an inevitable part of its performativity. A reflection should be undertaken as to the potential users of this type of framework and on how a diversity of uses may enhance its continuous improvement. Globally, with our approach, we wish to provide theoretical and methodological inputs for analysis of place-based struggles, which we hope will trigger deeper insights.

\section{Notes}

1. "Enlighten" is not used in the sense of illumination nor does it refer to the Enlightenment ideas but implies that a resistance movement can "shed light" on some issues.

2. Label made famous by the activists fighting against the airport project in Notre-Dames-Des-Landes, France.

3. To learn more about the case, see Milanesi, Metrich, and Henriet (2016).

4. These actions brought together between 400 and 1000 persons depending on the event and the case.

\section{Disclosure statement}

No potential conflict of interest was reported by the authors.

\section{References}

Agnew, J. 1987. Place and Politics. The Geographical Mediation of State and Society. Boston and London: Allen and Unwin. Altman, I., and S. Low. 1992. Place Attachment. New York: Plenum Press.

Anguelovski, I., and J. M. Martinez Alier. 2014. "The 'Environmentalism of the Poor' Revisited: Territory and Place in Disconnected Glocal Struggles." Ecological Economics 102: 167-176.

Armiero, M., and G. D'Alisa. 2012. "Rights of Resistance: The Garbage Struggles for Environmental Justice in Campania, Italy." Capitalism Nature Socialism 23 (4): 52-68. 
Batel, S., and P. Devine-Wright. 2015. "Towards a Better Understanding of People's Responses to Renewable Energy Technologies: Insights From Social Representations Theory." Public Understanding of Science 24 (3): 311-325.

Bourdieu, P. 1981. "La Représentation Politique, Éléments Pour une Théorie du Champ Politique." Actes de la Recherche en Sciences Sociales 36 (1): 3-24.

Bourdieu, P. 1986. "The Forms of Capital." In Handbook of Theory and Research for the Sociology of Education, edited by John G. Richardson, 241-258. New York: Greenwood.

Brehm, J. M., B. W. Eisenhauer, and R. C. Stedman. 2013. “Environmental Concern: Examining the Role of Place Meaning and Place Attachment." Society \& Natural Resources 26 (5): 522-538.

Brown, P. 1992. "Popular Epidemiology and Toxic Waste Contamination: lay and Professional Ways of Knowing." Journal of Health and Social Behavior 33 (3): 267-281.

Burningham, K. 2000. "Using the Language of NIMBY: A Topic for Research, Not an Activity for Researchers." Local Environment 5 (1): 55-67.

Busenberg, G. 1999. "Collaborative and Adversarial Analysis in Environmental Policy." Policy Sciences 32 (1): 1-11.

Coleman, J. S. 1988. "Social Capital in the Creation of Human Capital." American Journal of Sociology 94 (Supplement: Organizations and Institutions: Sociological and Economic Approaches to the Analysis of Social Structure): S95-S120.

Dear, M. 1992. "Understanding and Overcoming the NIMBY Syndrome." Journal of the American Planning Association 58: 288-300.

Devine-Wright, P. 2005. "Beyond NIMBYism: Towards an Integrated Framework for Understanding Public Perceptions of Wind Energy." Wind Energy 8 (2): 125-139.

Dudwick, N., K. Kuehnast, V. N. Jones, and M. Woolcock. 2006. "Analyzing Social Capital in Context." In A Guide to Using Qualitative Methods and Data, 5-7. Washington, DC: World Bank.

Escobar, A. 2006. "Difference and Conflict in the Struggle Over Natural Resources: A Political Ecology Framework." Development 49 (3): 6-13.

Ford, L. H. 2003. "Challenging Global Environmental Governance: Social Movement Agency and Global Civil Society." Global Environmental Politics 3 (2): 120-134.

Ghorra-Gobin, C. 2001. "Les Espaces Publics, Capital Social / Public Space and Social Capital." Géocarrefour 76 (1): 5-11.

Gibson, T. A. 2005. "NIMBY and the Civic Good." City and Community 4 (4): 381-401.

Grootaert, C. 1999. "Social Capital, Household Welfare, and Poverty in Indonesia." World Bank Policy Research Working Paper 2148. https://ssrn.com/abstract=569207.

Hidalgo, M. C., and B. Hernandez. 2001. "Place Attachment: Conceptual and Empirical Questions." Journal of Environmental Psychology 21: 273-281.

Holifield, R. 2015. "Environmental Justice and Political Ecology." In Routledge Handbook of Political Ecology, edited by T. Perreault, G. Bridge, and J. McCarthy, 585-597. London: Routledge.

Irwin, A. 1995. Citizen Science: A Study of People, Expertise and Sustainable Development. London: Routledge.

Latouche, S. 2015. "Imaginary (Decolonization of)." In Degrowth: A Vocabulary for a New Era, edited by G. D'Alisa, F. Demaria, and G. Kallis, 117-120. London: Routledge.

Louis, W. R. 2009. "Collective Action-And Then What?" Journal of Social Issues 65 (4): 727-748.

Martinez-Alier, J., L. Temper, D. Del Bene, and A. Scheidel. 2016. "Is There a Global Environmental Justice Movement?" The Journal of Peasant Studies 43 (3): 731-755.

Micoud, A. 2000. "Entre Loire et Rhône, ou comment des objets naturels peuvent faire du lien." In Ce qui nous relie, edited by A. Micoud, and M. Peroni, 227-239. La tour d'Aigues: Editions de l'Aube.

Milanesi, J., S. Metrich, and N. Henriet. 2016. Construire de nouvelles infrastructures de transports? Université Virtuelle Environnement et développement durable. http://sup.ups-tlse.fr/uved/infrastructures-transport/accueil/html/index.html.

Mouffe, C. 2005. On the Political. Abingdon - New York: Routledge.

Putnam, R. D. 2000. Bowling Alone: The Collapse and Revival of American Community. New York: Simon and Shuster.

Raymond, C. M., G. Brown, and D. Weber. 2010. "The Measurement of Place Attachment: Personal, Community, and Environmental Connections." Journal of Environmental Psychology 30 (4): 422-434.

Sebastien, L. 2013. "Le Nimby est Mort. Vive la Résistance éclairée: le cas de L'opposition à un Projet de Décharge, Essonne, France." Sociologies Pratiques 27 (2): 145-165.

Sebastien, L. 2016. "L'attachement au lieu, vecteur de mobilisation collectiveÉtude de cinq territoires ruraux." Norois 238239 (1-2): 23-41.

Sebastien, L. 2017. “From NIMBY to Enlightened Resistance: A Framework Proposal to Decrypt Land-use Disputes Based on a Landfill Opposition Case in France." Local Environment 22 (4): 461-477.

Silva, E., D. Wright, and A. Ward. 2009. "Using Mixed Methods for Analysing Culture: The Cultural Capital and Social Exclusion Project." Cultural Sociology 3 (2): 299-316.

Simon, B., and B. Klandermans. 2001. "Politicized Collective Identity: A Social Psychological Analysis." American Psychologist 56 (4): 319-331.

Sixsmith, J. 1986. "The Meaning of Home: An Exploratory Study of Environmental Experience." Journal of Environmental Psychology 6: 281-298.

Swyngedouw, E. 2000. "Authoritarian Governance, Power, and the Politics of Rescaling." Environment and Planning D: Society and Space 18 (1): 63-76. 
Trom, D. 1999. “De la Réfutation de L'effet NIMBY Considérée Comme une Pratique Militante. Notes Pour une Approche Pragmatique de L'activité Revendicative." Revue Française de Science Politique 49 (1): 31-50.

Van Deth, J. W. 2003. "Measuring Social Capital: Orthodoxies and Continuing Controversies." International Journal of Social Research Methodology 6 (1): 79-92.

Vinthagen, S., and A. Johansson. 2013. "Everyday Resistance': Exploration of a Concept and its Theories." Resistance Studies Magazine 1 (1): 1-46.

Wolsink, M., and J. Devilee. 2009. "The Motives for Accepting or Rejecting Waste Infrastructure Facilities. Shifting the Focus From the Planners' Perspective to Fairness and Community Commitment." Journal of Environmental Planning and Management 52 (2): 217-236. 